

\section{DECEMBER 1941}





\section{DECEMBER 1941}

Twelve Days that Began a World War

\section{Evan Mawdsley}


Copyright @ 2011 Evan Mawdsley

All rights reserved. This book may not be reproduced in whole or in part, in any form (beyond that copying permitted by Sections 107 and 108 of the US Copyright Law and except by reviewers for the public press) without written permission from the publishers.

For information about this and other Yale University Press publications, please contact:

US Office: sales.press@yale.edu_yalebooks.com

Europe Office: sales@yaleup.co.uk www.yalebooks.co.uk

Set in Minion by IDSUK (DataConnection) Ltd

Printed in Great Britain by TJ International Ltd, Padstow, Cornwall

Library of Congress Cataloging-in-Publication Data

Mawdsley, Evan, 1945-

December 1941 / Evan Mawdsley.

p. $\mathrm{cm}$.

Includes bibliographical references and index.

ISBN 978-0-300-15445-0

1. World War, 1939-1945. 2. World War, 1939-1945-United States. I. Title.

D743.M365 2011

940.53-dc23 